\title{
Upaya Optimalisasi Kinerja Pegawai Koperasi Serba Usaha (KSU) Padurenan Jaya Kudus Melalui Holiday Exchange
}

\author{
Moh. Nurul Qomar ${ }^{1}$, Nanang Dwi Praatmana ${ }^{2}$ \\ IAIN Kudus ${ }^{1}$, IAIN Kudus ${ }^{2}$ \\ mnqomar@iainkudus.ac.id ${ }^{1}$, nanangdp26@gmail.com²
}

\begin{abstract}
This article discusses human resource management approach Koperasi Serba Usaha (KSU) Padurenan Jaya so that the optimization of employee performance can be achieved. The approach in question is a holiday exchange. This study uses a qualitative method with a field research approach. The results of this study indicate that the holiday exchange approach applied at KSU Padurenan Jaya has proven to be able to improve services to members and increase the cooperative business results (SHU). The application of this system is also in accordance with Islamic business ethics, which refers to the value of unity and responsibility so that it affects the flexibility of management in determining holidays
\end{abstract}

Keywords: optimization of employee performance, holiday exchange, KSU Padurenan Jaya

Abstrak

Artikel ini membahas pendekatan manajemen sumber daya manusia pada Koperasi Serba Usaha (KSU) Padurenan Jaya sehingga diharapkan optimalisasi kinerja pegawai dapat tercapai. Pendekatan yang dimaksud adalah holiday exchange. Penelitian ini menggunakan metode kualitatif dengan pendekatan field research. Hasil penelitian ini meretas pendekatan holiday exchange yang diterapkan pada KSU Padurenan Jaya terbukti mampu meningkatkan pelayanan kepada anggota dan bertambahnya sisa hasil usaha (SHU) koperasi. Penerapan sistem ini juga sesuai dengan etika bisnis Islam, dimana mengacu pada nilai unity dan responsibility sehingga berdampak pada keluesan manajemen dalam menentukan hari libur

Kata Kunci: optimalisasi kinerja pegawai, holiday exchange, KSU Padurenan Jaya

\section{PENDAHULUAN}

Keberhasilan dalam mengembangkan ekonomi di desa Padurenan tidak terlepas dari spirit gusjigang sebagai filosofi kehidupan masyarakat kudus. Masyarakat kudus dikenal berkarakter giat berdagang dan tekun dalam belajar, yang merupakan perwujudan dari ajaran gusjigang, yang berarti bagus, ngaji dan dagang. Spirit gusjigang merupakan kearifan lokal Kabupaten Kudus yang berasal dari ajaran Sunan Kudus. Nilai ini menjadi glokalitas yang handal yang mampu menjadi karakter universal. Nilai universal ini dapat menjadi modal dasar dalam menghadapi persaingan bebas, sehingga pelaku bisnis akan senantiasa berbuat adil dan jujur (Mustaqim \& Bahrudin, 2015). Mampu disimpulkan bahwa spirit gusjigang 
telah mengakar dalam kehidupan masyarkat kudus, jadi nilai-nilai ekonomi syariah telah terinternalisasi pada masyarakat kudus jauh sebelum munculnya istilah ekonomi syariah itu sendiri.

Kabupaten Kudus merupakan salah satu kabupaten di Provinsi Jawa Tengah yang telah memiliki banyak UMKM. Salah satunya sentral pengembangan UMKM terletak di Desa Padurenan. Desa Padurenan Kecamatan Gebog Kabupaten Kudus terdapat sekitar 180 UKM pengrajin Bordir dan Konfeksi, yang bertumbuh kembang secara alami sejak belasan bahkan puluhan tahun. Dari Pengrajin tersebut dapat mampu menyerap sekitar 1500 tenaga kerja. Dari populasi usaha tersebut, sekitar $65 \%$ merupakan unit usaha konfeksi dan 35\% adalah unit usaha bordir. Sebagian besar hasil produk dipasarkan di wilayah Jawa Tengah, Jawa Timur, Bali, dan daerah lainnya.

Dari sekian banyak UMKM yang berkembang di desa Padurenan, terdapat unit bisnis yang berbentuk koperasi, yaitu Koperasi Serba Usaha Padurenan Jaya. Berdasarkan observasi awal peneliti, Koperasi Serba Usaha (KSU) Padurenan Jaya yang beralamat di Jln. Kyai Hasyim Gang I No.4 Rt 01/01 Padurenan Kecamatan Gebog, Kabupaten Kudus. Koperasi ini didirikan dengan berbadan hukum nomor: 503/208/BU/21/2009. Secara resmi koperasi ini berdiri pada tanggal 22 April 2009 dan diresmikan oleh Bupati Kudus pada periode itu. Fokus pada usaha bordir serta penjualan bahan serta hasil border.

Pendirian koperasi ini merupakan bagian grand desain pengembangan desa Padurenan sebagai desa Produktif. Keberadaan koperasi diharapkan mampu meningkatkan produktifitas UMKM sekitarnya dan menjadi media penghubung dengan Pemerintah kabupaten Kudus dalam pengembangan UMKM di desa Padurenan. Urgensi keberadaan KSU Padurenan Jaya tidak diragukan lagi, dibutuhkan kerja sama perangkat desa pengurus koperasi dan anggota koperasi untuk bersama-sama memajukan KSU Padurenan Jaya. Dinamika dalam berkoperasi merupakan hal yang menarik untuk diteliti, KSU Padurenan Jaya telah menjadi locus dalam penelitian, salah satunya penelitian Safari yang menunjukkan bahwa besarnya pengaruh pengetahuan perkoperasian di KSU Padurenan Jaya sebesar 25,4\%, motivasi berkoperasi KSU Padurenan Jaya sebesar 23,8\% dan kualitas pelayanan sebesar di KSU Padurenan Jaya 11,9\%. Masih menurut beliau, pengetahuan perkoperasian, motivasi berkoperasi dan kualitas pelayanan berpengaruh terhadap partisipasi anggota sebesar 65,3\% pada KSU Padurenan Jaya (Safari, 2015).

Berdasarkan penelitian tersebut diketahui bahwa kualitas pelayanan KSU Padurenan Jaya masih dikategorikan rendah. Jumlah pegawai KSU Padurnan Jaya saat ini berjumlah 14 pegawai, sedangkan jumlah anggota berjumlah 160 orang. Artinya struktur organisasi maupun segala peraturan yang ada pada koperasi tersebut masih sederhana. 
Tabel 1.1

Data Pegawai

KSU Padurenan Jaya

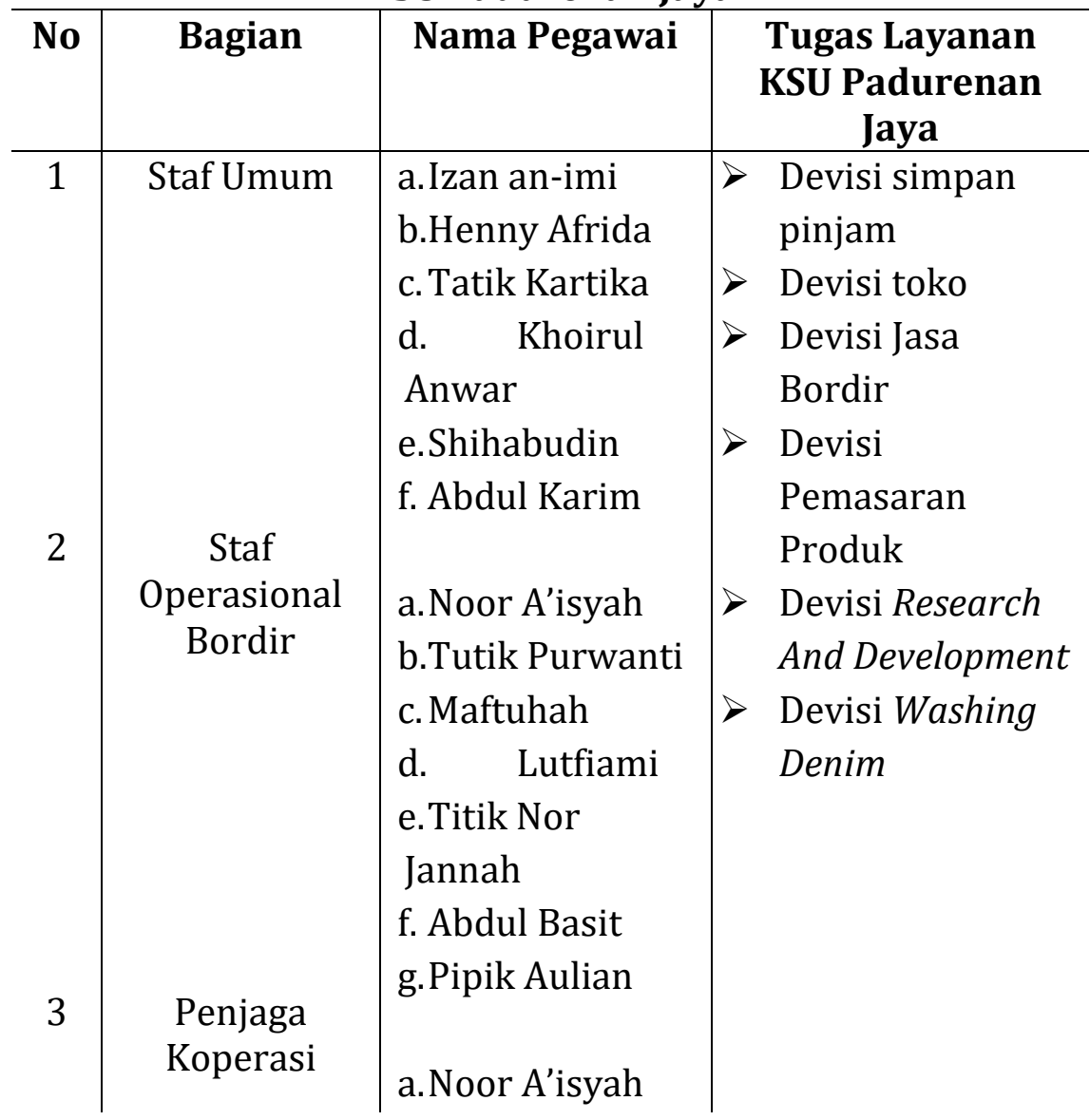

KSU Padurenan Jaya dengan jumlah pegawai terhitung minim, sehingga optimalisasi kinerja perlu ditingkatkan. Upaya optimalisasi kinerja pegawai perlu dilakukan mengingat pegawai merupakan motor penggerak produksi maupun distribsi. Misalnya penelitian Ahyar menyebutkan optimalisasi pegawai balai benih ikan Sukamaju Kabupaten Ciamis telah dilakukan dengan baik sesuai dengan indikator kinerja (Ahyar, 2015).

Pada penelitian tersebut membuktikan bahwa baik di lingkungan pemerintahan maupun swasta, optimalisasi pegawai mutlak wajib dilakukan untuk memaksimalkan kinerja. Penelitian lainnya yang secara spesifik membahas optimalisasi kinerja dan koperasi dilakukan oleh Hermawati dan Mas. Hasil penelitian tersebut menyebutkan optimalisasi penerapan quality of work life dan keterlibatan pegawai mampu meningkatkan kinerja pegawai koperasi berprestasi di Jawa Timur (Hermawati \& Mas, 2017). Tercapainya hasil yang maksimal pada perusahaan bukan hanya tergantung pada peralatan modern, sarana dan prasarana yang mutakhir, akan tetapi faktor sumber daya manusia yang mempunyai pengaruh pada kinerja perusahaan (Endarwita \& Herlina, 2016). 
Manajemen sumber daya manusia pada perusahaan tentu berbeda dengan manajemen sumber daya manusia pada koperasi. Koperasi yang mempunyai azaz kekeluargaan harus mampu secara fleksibel menyelesaikan permasalahan yang dihadapi. Menariknya pada KSU Padurenan Jaya menghadapi perselisihan pegawai dalam menentukan hari libur. Pegawai perempuan menghendaki hari libur pada hari minggu, mengingat hari libur pada umumnya adalah hari minggu, sedangkan pegawai laki-laki menginginkan hari libur pada hari Jum'at dengan asumsi ibadah sholat jum'at tidak terganggu dengan aktivitas kerja.

Bagi pihak manajemen sebetulnya hanya menginginkan layanan KSU Padurenan Jaya berjalan dengan lancer, sehingga pihak manajemen dalam mengontrol pegawai dalam hal kehadiran dalam kerja masih sebatas wajar seperti izin sakit, keperluan penting dll. Untuk mengantisipasi adanya pegawai yang izin, Pihak manajemen menambahkan pegawai berstatus kerja borongan dan selalu menambahkan sikap untuk saling komunikasi.

Namun untuk hari libur, pihak manajemen berupaya untuk menentukan sebaik mungkin tanpa mengurangi hak sedangkan pihak pegawai dapat bekerja nyaman tanpa mengurangi kinerja. Mengingat pengembangan organisasi bisnis dapat terkendali apabila sumber daya manusia (pegawai) dikelola dengan baik. Hal ini dilakukan agar kinerja pegawai dapat optimal (Rosmadi, 2018).

\section{KAJIAN LITERATUR Penelitian Terdahulu}

Rosyad, Narulita dan Hadiyanto dalam Jurnal Studi Al-Qur'an menyebutkan bahwa melalui kegiatan-kegiatan seperti pengajian bulanan, i'tikaf di bulan ramadhan, kewajiban berjilbab, dan pelarangan merokok, shalat berjamaah dan shalat sunnah. Penerapan nilai spiritual tersebut memberikan dampak yang optimal bagi kinerja pegawainya, kecuali pada poin kehadiran di tempat kerja yang tidak optimal, karena pegawai pada bagian invoice, persentase keterlambatannya mencapai maksimal 38\% (Rosyad, Narulita, \& Hadiyanto, 2015).

Penelitian tersebut dilakukan di perusahaan yang bukan berlabel "syariah", namun focus peneliannya pada kinerja pegawai semakin optimal dengan hadirnya nilai-nilai spiritual di tengah-tengah rutinitas kerja. Pada penelitian ini mencoba mengungkap optimalisasi kinerja pegawai dengan pendekatan berbeda.

Penelitian Zahra dkk, membuktikan pengaruh yang signifikan variabel pengalaman kerja dan curahan jam kerja terhadap kinerja pegawai (studi kasus pada home industry tas pita plastik bapak Almunir di Desa Setail, Kecamatan Genteng, Kabupaten Banyuwangi tahun 2017) yaitu dengan persentase sebesar 87,7\%. Diantara variabel pengalaman kerja dan curahan jam kerja, variabel pengalaman kerja (X1) mempunyai pengaruh yang dominan terhadap kinerja pegawai pada home industry tas pita plastik bapak 
Almunir di Desa Setail, Kecamatan Genteng, Kabupaten Banyuwangi tahun 2017 yaitu sebesar 57,7\% (Zahro, Suyadi, \& Djaja, 2018).

Penelitian lainnya dari Isti'adzah dan Mas'ud (2017) yang mengungkapkan bahwa dalam tata kelola SDM Ayam Bakar Wong Solo Cabang Simongan berpijak pada nilai-nilai Islam yaitu tauhid, khalifah, keadilan, persaudaraan, ihsan dan musyawarah. Nilai- nilai tersebut bukan hanya menjadi dasar fungsi- fungsi manajemen sumber daya manusia, akan tetapi sudah menjadi ruh dalam keseluruhan kegiatan bisnis.

Dari hasil penelusuran penelitian terdahulu di atas, peneliti menyimpulkan begitu banyak factor yang mempengaruhi kinerja, sehingga dibutuhkan berbagai pendekatan atau strategi dalam optimalisasi kinerja pegawai.

\section{Landasan Teori}

Berbagai pendekatan dilakukan sebagai strategi untuk mencari dasar keunggulan demi ketercapaian tujuan bisnis. Beberapa tujuan strategi di antaranya sebagai berikut: Pertama, mengejar untuk mencapai biaya rendah (overall Cost Leadership) dalam industri. Untuk pengendalian biaya dalam overal cost leadership dilakukan efesiensi biaya yang dapat diperoleh dari memiliki pegawai yang berpengalaman, pengendalian biaya everhead, meminimalkan biaya penelitian dan pengembangan, service, wiraniaga, periklanan dan lain sebagainya. Kedua, mengejar untuk mencaiptakan produk yang unik untuk pelanggan yang bervariasi atau differensiasi (differentiation). Differensiasi dapat dilakukan melalui dimensi citra rancangan atau merk, teknologi yang digunakan, karakteristik khusus, service pada pelanggan dan punya distribusi yang lebih baik. Keunggulan dalam menggunakan differensiasi selain laba di atas rata-rata adalah kepekaan konsumen terhadap harga kurang, produk-produk differensiasi menciptakan hambatan masuk yang tinggi dan posisi terhadap produk pengganti juga tinggi. Ketiga, mengejar untuk melayani permintaan khusus pada satu atau beberapa kelompok konsumen atau industri. Memfokuskan (focusting) pada biaya atau diferensiasi(Suci, 2009).

\section{Manajemen Bisnis Islam}

Definisi manajemen bisnis Islami menurut Mas'ud (2017) adalah sebagai prinsip-prinsip manajemen bisnis berdasarkan pandangan hidup Islam. Bisnis Islami mempunyai rambu-rambu yang telah tertulis dalam al Quran dan al Hadis. Berbeda dengan bisnis konvensional tujuan utamanya adalah mencari keuntungan yang hanya bersifat duniawi, sedangkan bisnis Islami bertujuan bukan hanya keuntungan duniawi namun ingin mencapai keuntungan ukhrawi dengan ditopang nilai-nilai sebagai berikut: a. Tauhid b. Khalifah c. Keadilan d. Persaudaraaan e. Ihsan f. Musyawarah(Mas'ud, 2017).

Hal tersebut di atas selaras dengan motivasi kerja dalam Islam yang tidak hanya ditujukan untuk memperoleh harta melimpah untuk kesenangan di dunia semata dengan menghalalkan segala cara, melainkan motivasi islami 
hadir untuk memberikan pandangan kepada pegawai bahwa bekerja secara giat bukan hanya bernilai dalam pandangan atasan, namun bekerja merupakan bentuk ibadah dan bernilaih juga di hadapan Allah (Anoraga \& Prasetyo, 2015).

\section{METODE PENELITIAN}

Pada penelitian ini peneliti menggunakan jenis penelitian Field reearch. Penelitian field research adalah penelitian yang dilakukan dengan jalan peneliti mendatangi langsung ke locus penelitian. Penelitian ini menggunakan pendekatan kualitatif adalah prosedur penelitian yang menghasilkan data deskriptif berupa kata-kata tertulis atau lisan dari orang-orang dan perilaku yang diamati. Penelitian ini termasuk penelitian kualitatif deskriptif. Metode deskriptif adalah metode yang dilakukan untuk mengetahui nilai variabel mandiri, baik satu variabel atau lebih (independen) tanpa membuat perbandingan, atau menghubungkan dengan variabel yang lain.

Semua jenis penelitian dimulai dari perumusan masalah. Penelitian kualitatif mencari dan mendapatkan masalah dengan cara induktif. Peneliti harus datang ke latar penelitian, berada disana dalam waktu yang memadai dan menggali masalah menggunakan cara berinteraksi dengan cara partisipan yaitu subjek pemilik realitas yang akan diteliti.

Subyek dalam penelitian ini adalah manajer, pegawai serta anggota KSU Padurenan Jaya. Teknik pengumpulan data menggunakan wawancara dan observasi. Adapun langkah-langkah analisis yang peneliti lakuka adalah reduksi data (data reduction), penyajian data (data display), dan verifikasi (conclusion drawing). Pada penelitian ini difokuskan untuk upaya optimalisasi kinerja pegawai melalui holiday exchange di KSU Padurenan Jaya dalam skala waktu selama 3 (tiga) tahun terakhir, yaitu pada tahun 20162018.

\section{PEMBAHASAN}

\section{Profil Koperasi Serba Usaha Paduranan Jaya}

Desa Padurenan terletak sekitar $7 \mathrm{~km}$ dari pusat kota Kudus. Desa Padurenan berada pada wilayah Kecamatan Gebog Kabupaten Kudus. Desa dikenal sebagai sentra konveksi, terdapat sekitar 180 UKM pengrajin bordir dan konveksi, yang bertumbuh kembang sejak belasan bahkan puluhan tahun yang lalu.

Secara keseluruhan UKM di Desa Padurenan mampu menyerap sekitar 1500 tenaga kerja. Dari populasi usaha tersebut, sekitar 65\% merupakan unit usaha konveksi dan 35\% adalah unit usaha bordir. Sebagian besar hasil produk dipasarkan di wilayah Jawa Tengah, Jawa Timur, Bali, dan daerah lainnya. Selain itu di desa ini terdapat UKM Jenang dan Tas.

Interfensi pemerintah dalam tata kelola UKM di desa Padurenan dimulai pada tahu 2008 dengan program Bali Ndeso Mbangun Ndeso yang diprakarsai oleh Bapak Bibit Waluyo sebagai Gubernur Provinsi Jwa Tengah pada waktu itu. Program tersebut dilaksanakan secara terpadu sinergis oleh 
semua pihak sehingga mampu mempercepat pemberdayaan pedesaan, termasuk di desa padurenan.

Kerja sama dilakukan dengan berbagai pihak termasuk dengan Bank Indonesia, KBI semarang, Dinas Tenaga Kerja, Transmigrasi dan kependudukan Propinsi Jawa Tengah, balai besar Peningkatan Produkstivitas (BBPP), Direktoral Jendral Pembinaan Pelatihan dan Produktivitas, Depnakertrans RI, Bank Jwa Tengah, GTZ Red dan Pemerintah Kabupaten Kudus sebagai upaya pengembangan desa padurenan sebagai desa produktif klaster border dan konveksi.

Dalam perkembangannya diperlukan wadah untuk menyamakan visi dan misi desa Padurenan sebagai desa produktif, maka dibentuklah koperasi. Koperasi ini didirikan dengan berbadan hukum nomer 503/208/BU/21/2009 yang kemudian diberi nama Koperasi Serba Usaha Padurenan Jaya. Secara resmi koperasi ini berdiri pada tanggal 22 April dan diresmikan oleh Bupati Kudus pada periode itu.

Visi Koperasi Serba Usaha Padurenan Jaya adalah "Menjadikan desa Padurenan sebagai klaster wisata yang memiliki produktifitas serta daya saing industri yang tinggi sehingga menjadi penggerak bagi pertumbuhan ekonomi desa sekitarnya." Adapun Misinya adalah sebagai berikut: a. Pemberdayaan masyarakat di desa produktif padurenan sebgai manusia religious, kreatif, produktif dan memiliki etika bisnis serta modal sosial yang tinggi.b. Mendorong keterlibatan aktif dari aparatur pemerintah dalam pembangunan fisik / infrastruktur serta stakeholder terkait dalam peningkatan daya saing industry bordir dan konveksi sehingga mendukung terwujudnya Diamond Cluster dan Konveksi di desa Produktif Padurenan Kudus. c. Mendorong bertumbuhnya berbagai industry pendukung serta jaringan usaha yang bersinergi untuk peningkatan daya saing diamond cluster bordir dan konveksi di desa Produktif Padurenan Kudus.

\section{HASIL}

Sama halnya dengan koperasi lainnya, KSU Padurenan Jaya dalam operasionalnya berpijak pada azas kekeluargaan termasuk dalam hal manajemen sumber daya manusia. Awal penentuan hari libur bagi pegawai KSU Padurenan Jaya dilakukan secara musyawarah. Pada waktu itu terjadi perbedaan pendapat antara pegawai laki-laki dengan pegawai perempuan. Di tempat kerja yang lain mempertahankan atau mengganti pegawai jika terjadi perselisihan merupakan bagian fenomena tersendiri di dunia kerja. Di Polandia, pergantian pegawai adalah fenomena yang lebih sering disebabkan oleh tindakan pegawai itu sendiri (Skowron-mielnik \& Golembski, 2019). Pegawai laki-laki menghendaki hari libur pegawai pada hari jum'at, sedangkan pegawai perempuan menghendaki hari libur pada hari minggu.

Pegawai laki-laki menginginkan libur di hari Jumat sebab seluruh pegawai di KSU Padurenan Jaya beragama Islam dan kultur masyarakat di Padurenan setiap usaha libur di Hari Jumat. Sedangkan pegawai perempuan 
menginginkan libur di hari minggu karena pegawai di sekitar padurenan libur di Hari Minggu. KSU Padurenan Jaya menerapkan sistem ini dengan tujuan tetap menjaga persatuan dan menghindarkan perselisihan antar pegawai serta menerapkan prinsip etika bisnis Islam pada usaha yang dijalankan.

Holiday exchange merupakan sebuah strategi dimana operasional perusahaan berlangsung selama 7 hari, namun pegawai tetap mendapatkan haknya untuk libur, yaitu dengan cara libur bergantian dalam satu minggu. KSU Padurenan Jaya menetapakn hari libur untuk pegawai laki-laki pada hari jumat dan pegawai perempuan pada hari minggu.

Pendekatan holiday exchange di KSU Padurenan Jaya, jika diretas dalam kajian etika bisnis Islam akan terungkap beberapa hal, di antaranya:

1. Unity (Persatuan)

Unity (persatuan) tercermin pada konsep tauhid. Konsep ini merupakan azas fundamental seorang muslim dalam melakukan kegiatan ekonomi, sosial, politik budaya menjadi keseluruhan yang homogen, konsisten dan teratur. Pada konsep tauhid terdapat dimensi vertikal (manusia dengan penciptanya) dan horizontal (sesama manusia).

Allah telah menjelasakan bahwa umat Islam tidak boleh bercerai berai dan harus bersatu untuk menjaga tali persaudaraan dan menjunjung tinggi nilai-nilai toleransi dalam setiap kegiatan yang dilaksanakan, tidak terkecuali dalam kegiatan bisnis. Diterangkan dalam Al Quran Surat Ali Imran Ayat Ali Imran ayat 103:

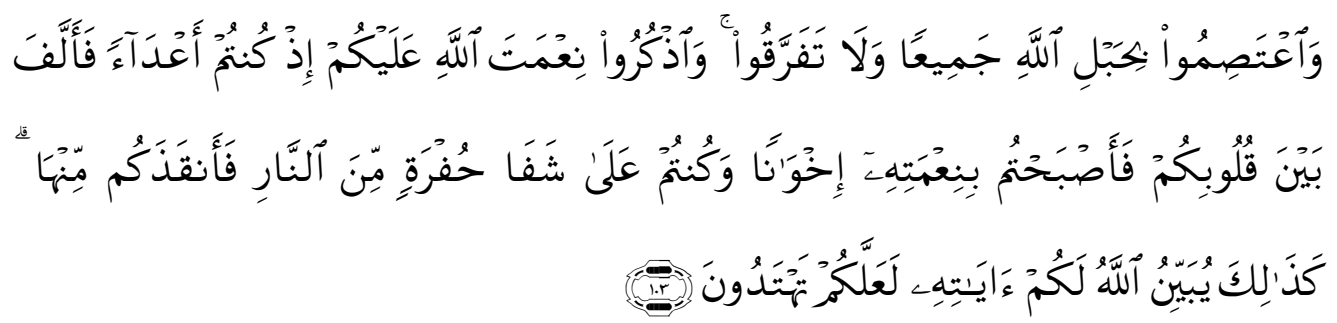

Artinya: "dan berpeganglah kamu semuanya kepada tali (agama) Allah, dan janganlah kamu bercerai berai, dan ingatlah akan nikmat Allah kepadamu ketika kamu dahulu (masa Jahiliyah) bermusuh-musuhan, Maka Allah mempersatukan hatimu, lalu menjadilah kamu karena nikmat Allah, orang-orang yang bersaudara; dan kamu telah berada di tepi jurang neraka, lalu Allah menyelamatkan kamu dari padanya. Demikianlah Allah menerangkan ayat-ayat-Nya kepadamu, agar kamu mendapat petunjuk." Interprestasi ayat tersebut di atas dalam konteks pegawai di KSU Padurenan Jaya adalah pegawai tetap diberikan hak libur sesuai dengan keinginan dengan syarat dan ketentuan berlaku (komitmen pegawai), sehingga terciptanya keharmonisan antar pegawai sekaligus KSU Padurenan Jaya mempunyai distingsi dibanding dengan koperasinya dengan pelayanan anggota dalam 7 hari kerja. 
2. Responsibility (Tanggung Jawab)

Ketentuan hari libur pegawai melalui forum musyawarah, kedepannya tanggung jawab pegawai lebih meningkat sehingga optimalisasi kinerja pegawai tercapai. Selama ini pegawai KSU Padurenan Jaya berasal dari lingkungan usaha desa Padurenan sebagai bentuk tanggung jawab sosial yang dilakukan. Selain itu KSU Padurenan Jaya memberikan gaji sesuai dengan jam kerja, apabila pegawai menginginkan jam lembur, maka KSU Padurenan Jaya akan memberikan upah yang sesuai dengan apa yang telah dikerjakan. Bentuk tanggung jawab KSU Padurenan Jaya yang lain adalah membayar pajak tepat waktu sesuai dengan peraturan negara, dan mengeluarkan zakat sesuai dengan anjuran Agama Islam sebagai bentuk ketaatan dan tanggungjawab terhadap negara dan agama.

Implemetasi pendekatan holiday exchange dalam optimalisasi kinerja pegawai dimulai pada tahun 2016 sampai sekarang. Menurut manajer KSU Padurenan Jaya dampak positif yang nampak dari penerapan holiday exchange adalah jumlah sisa hasi usaha (SHU) yang diperoleh KSU Padurenan Jaya tahun 2016-2018 tergambar pada grafik berikut ini:

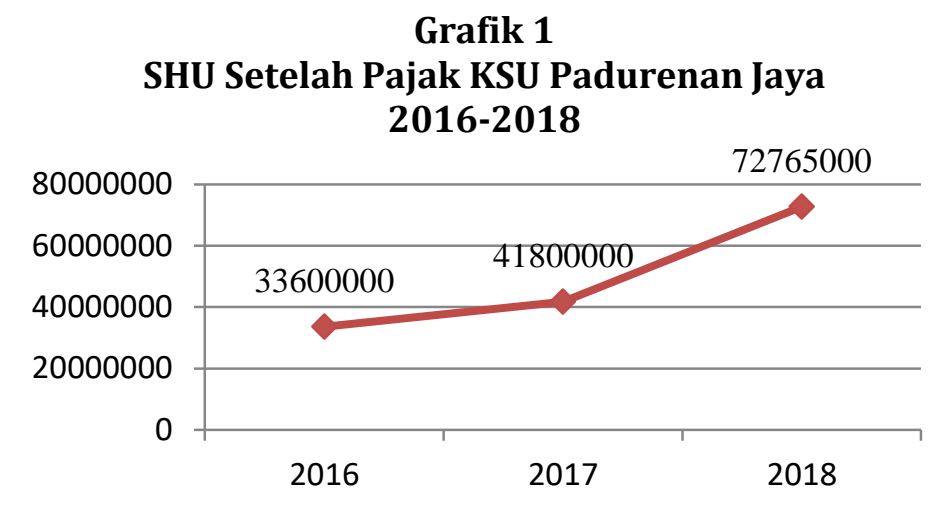

Sumber : Laporan Pertanggungjawaban dan Rapat Anggota KSU Padurenan Jaya 2016-2018

Berdasarkan grafik di atas trend kenaikan sisa hasil usaha (SHU) KSU Padurenan Jaya mengalami kenaikan pada awal penerapan yaitu pada tahun 2016-2017 namun belum menunjukkan angka yang signifikan. Pada tahun 2017 KSU Padurenan Jaya memiliki keuntungan yang lebih besar dari tahun 2016 yaitu dengan selisih keuntungan Rp8.200.000.

Walaupun memperoleh keuntungan yang lebih tinggi di tahun 2017, namun penerapan strategi ini belum sesuai apa yang diinginkan oleh KSU Padurenan Jaya, ada beberapa kendala yang dialami selama pelaksanaan uji coba sistem ini, anatara lain komposisi pegawai yang tidak seimbang dan kemampuan pegawai yang tidak merata.

Pada tahap awal penerapan holiday exchange, pihak manajemen KSU Padurenan Jaya melakukan langkah-langkah sebagai berikut:

1. Perencanaan 
Pada tahap perencanaan manajer KSU Padurenan Jaya Kudus melakukan analisa keberlangsungan operasinal melalui potensi sumberdaya yang dimiliki dengan cara melakukan wawancara terhadap pegawai laki-laki dan perempuan yang dipilih secara acak untuk mendapatkan masukan sebelum strategi tersebut diterapkan. Hal ini dilakukan untuk mendengarkan kesiapan dari pegawai untuk diberlakukannya holiday exchange. Selain itu juga melakukan analisis biaya guna memperhitungkan efisiensi biaya yang akan dikeluarkan untuk operasional.

2. Pelaksanaan dan uji coba

Setelah dilakukan analisa awal strategi tersebut ditawarkan dan disepakati oleh pegawai. Uji coba dilaksanakan selama satu tahun mulai 2016-2017 untuk melihat perkembangan awal sejak diterapkannya strategi ini yang kemudian akan dilaksanakan evaluasi dan tindak lanjut atas hasil yang akan dicapai nantinya. KSU Padurenan Jaya tidak serta merta menerapkan suatu strategi tanpa melakukan uji coba, sebab penerapan strategi tidak selamanya akan berjalan sesuai dengan apa yang diinginkan. Uji coba dilakukan untuk melihat progres dan perkembangan dari strategi yang diterapkan.

3. Pengawasan

Pada tahap awal penerapan strategi, manajer malakukan pengawasan dengan melihat kinerja pegawai serta hasil operasional yang dicapai. Pegawai merasa strategi holiday exchange tepat dilaksanakan, karena kegiatan produksi dapat tetap berjalan namun mereka tetap mendapatkan haknya untuk libur. Pada awal proses penerapan sistem ini mendapatkan kendala dikarenakan sumberdaya manusia yang tidak seimbang dari segi komposisi gender pegawai, sehingga hasil yang dicapai belum menunjukkan pertumbuhan yang signifikan.

Pada tahun 2018 dapat dilihat bahawa KSU Padurenan Jaya mendapatkan keuntungan yang lebih tinggi dibandingkan pada tahun 2017 yaitu dengan selisih keuntungan Rp30.965.000. Menurut Manajer KSU Padurenan Jaya hal ini disebabkan adanya evaluasi dan perbaikan yang dilakukan oleh KSU Padurenan Jaya dengan melakukian pelatihan kepada pegawai agar mampu ditempatkan di segala posisi. Sehingga, apabila diberlakukan strategi holiday exchange tidak mengalami kendala lagi.

Selain melakukan wawancara kepada pegawai, manajer juga melakukan wawancara kepada pelanggan terkait kepuasan pelalyanan pada saat diterapkannya strategi holiday exchange. Pelanggan mengaku puas karena pesanan yang dilakukan dapat diambil tepat waktu sesuai dengan kesepaktan yang telah ditentukan diawal dan bisa diambil kapanpun karena KSU Padurenan Jaya beroperasional selama 7 hari.

4. Umpan balik

Dari penilaian yang telah dilakukan, manajer mendapatkan kendala dalam pelaksanaan holiday exchange yang perlu untuk di perbaiki. 
Upaya Optimalisasi Kinerja Pegawai Koperasi Serba Usaha (KSU) Padurenan Jaya Kudus Melalui Holiday Exchange

Urgensi umpan balik secara berkelanjutan, dan evaluasi berbasis kompetensi merupakan variable yang mempengaruhi secara positif kinerja pegawai, sebagaimana penelitian Ngugi dan Bula di sekolahsekolah umum di Kabupaten Kiambu (Ngugi \& Bula, 2019).

Manajer dapat mengambil simpulan dan tindakan evalusi guna perbaikan di masa yang akan datang. Setelah melihat kendala dan melakukan analisis lapangan manajer berupaya untuk mencari solusi agar permasalahan tersebut dapat diatasi. Adapun solusi yang dilaksanakan untuk menjawab permasalahan tersebut Melaksanakan pelatihan sesuai kompetensi yang dibutuhkan KSU Padurenan Jaya, meliputi pemilahan bahan baku produksi, desain bordir, proses membordir dan finishing sampai proses akhir yaitu packing dan pendistribusian kepada pelanggan dengan tujuan menyamakan kemampuan SDM, agar pegawai dapat saling backup apabila salah satu diliburkan atau tidak masuk kerja.

Selain meminta pendapat dan masukan dari pegawai KSU Padurenan Jaya Kudus, manajer juga rutin meminta pendapat dari pelanggan atas kinerja dari KSU Padurenan Jaya Kudus. Dari hasil kritik, saran maupun keluh kesah dari pelanggan, manajer dapat memperbaiki kebijakan dan strategi yang telah ditetapkan, agar tujuan usaha dapat tercapai sesuai target yang diinginkan.

\section{SIMPULAN}

Holiday exchange yang diterapkan pada KSU Padurenan Jaya terbukti mampu meningkatkan pelayanan kepada anggota dan bertambahnya sisa hasil usaha (SHU) koperasi. Penerapan sistem ini juga sesuai dengan etika bisnis islam, dimana mengacu pada nilai unity dan responsibility sehingga berdampak pada keluesan manajemen dalam menentukan hari libur. Di sisi lain dengan operasional KSU Padurenan Jaya selama 7 hari. Pendekatan ini juga tetap mempertahankan dan menjunjung kearifan lokal budaya setempat yang mayoritas usaha diliburkan pada hari Jumat sebagai rasa hormat atas mayoritas agama yang dianut oleh pegawai di UKM yang ada di Desa Padurenan.

\section{DAFTAR PUSTAKA}

Ahyar. (2015). Optimalisasi Kinerja Pegawai Balai Benih Ikan Sukamaju Dalam Rangka Penyediaan Benih Ikan Di Kabupaten Ciamis. Moderat: Jurnal Ilmiah Ilmu Pemerintahan, 1(3), 291-300.

Anoraga, B., \& Prasetyo, A. (2015). Motivasi Kerja Islam dan Etos Kerja islam Karyawan Bank Jatim Syariah Cabang Surabaya. Jurnal EKonomi SYariah Teori Dan Terapan, 2(7).

Endarwita, \& Herlina, R. (2016). Pengaruh Kompensasi dan Pengembangan Karir Terhadap Kinerja Karyawan (Studi kasus pada PT. FIF Group di 
Kabupaten Pasaman). E-Jurnal Apresiasi Ekonomi, 4(2), 100-117.

Hermawati, A., \& Mas, Na. (2017). Implementasi Quality of Work Life Dan Keterlibatan Pekerjaan Berbasis Transglobal Leadership Sebagai Upaya Strategi Pencapaian Optimalisasi Kinerja Karyawan (Studi Koperasi Berprestasi Di Jawa Timur). Jurnal Riset Ekonomi Dan Manajemen (JREM), 17(2), 163-177.

Isti'adzah, I., \& Mas'ud, F. (2017). Penerapan Nilai-Nilai Islam Dalam Praktik Manajemen Sumber Daya Manusia (Studi Pebisnis Muslim Pada Ayam Bakar Wong Solo Cabang Simongan). Diponegoro Journal of Management, $6(2), 1-14$.

Mas'ud, F. (2017). Manajemen Bisnis Berbasis Pandangan Hidup Islam (1st ed.). Semarang: Badan Penerbit UNiversitas Diponegoro.

Mustaqim, M., \& Bahrudin, A. (2015). Spirit Gusjigang Kudus dan Tantangan Globalisasi Ekonomi. Jurnal Penelitian, 9(1).

Ngugi, E. W., \& BUla, H. (2019). Performance Management Practices And Employee Performance In Selected Public Schools In Kiambu County, Kenya. International Academic Journal of Human Resource and Business Administration, 3(7), 533-551.

Rosmadi, M. L. N. (2018). Optimalisasi Kinerja Karyawan Dalam Pengembangan Organisasi Bisnis. Iqtishadia:Jurnal Ekonomi Dan Perbankan Syariah, 5(1).

Rosyad, I., Narulita, S., \& Hadiyanto, A. (2015). Upaya Optimalisasi Kinerja Pegawai Melalui Penerapan Nilai-Nilai Spiritualitas Islam (Studi Kasus di PT. Pandu Siwi Sentosa). Jurnal Studi Al-Qur'an: Membangun Tradisi Berfikir Qur'ani, 11(2), 145-156.

Safari, H. N. (2015). Pengaruh Pengetahuan Perkoperasian, Motivasi Berkoperasi Dan Kualitas Pelayanan Terhadap Partisipasi Anggota Koperasi Serba Usaha (Ksu) Padurenan Jaya Gebog Kabupaten Kudus. Universitas Negeri Semarang.

Skowron-mielnik, B., \& Golembski, M. (2019). Employee turnover as a factor in the optimization of HR processes Rotacja pracowników jako czynnik optymalizacji procesów kadrowych. Management Forum, 7(1), 8-13. https://doi.org/10.15611/mf.2019.1.02

Suci, R. P. (2009). Peningkatan Kinerja Melalui Orientasi Kewirausahaan, Kemampuan Manajemen, dan Strategi Bisnis (Studi pada Industri Kecil Menengah Bordir di Jawa Timur). Jurnal Manajemen Dan Kewirausahaan, 11(1), 48.

Zahro, H. M., Suyadi, B., \& Djaja, S. (2018). Pengaruh Pengalaman Kerja Dan Curahan Jam Kerja Terhadap Kinerja Karyawan (Studi Kasus Pada Home Industry Tas Pita Plastik Bapak Almunir Di Desa Setail Kecamatan Genteng Kabupaten Banyuwangi Tahun 2017). Jurnal Pendidikan Ekonomi, 12(1), 8-14. https://doi.org/10.19184/jpe.v12i1.6464 